\title{
The Role of Archaeological and Cultural-Historical Records in Long-range Coastal Fisheries Resources Management Strategies and Policies in the Pacific Islands
}

\author{
P. Dalzell
}

Current address: Western Pacific Fisheries Council, Suite 1405, 1164 Bishop St, Honolulu, HI 96813, USA

Draft paper for submission to "Ocean and Coastal Management" 1997

\section{ABSTRACT}

Humans settled most of the Pacific Islands over the last three millennia although settlement in Western Melanesia dates from the late Pleistocene, or a period of about 30 millennia. Archaeological studies conducted in the Pacific Islands over the past half century contain information on the long-term subsistence exploitation of fish and invertebrates from nearshore coral reefs and lagoons. Molluscs appear have been very important as a food source for early human colonists in the Pacific Islands, and declines in abundance through harvest pressure and environmental effects forced a greater reliance on fin-fish capture and on agriculture. There is no firm evidence from the archaeological record to suggest that longterm subsistence exploitation of reef fish populations has had any serious negative effects on abundance or structure of reef fish communities. An example of a subsistence reef fishery in Papua New Guinea, extending over a period of nearly four millennia, argues for long-term stability of the exploited reef fish populations. The utility of conventional fisheries science for long-term fisheries management and policies in the resource-poor islands of the Pacific is very limited. To be truly effective, coastal fisheries management in the Pacific Islands should be truly multi-disciplinary profession, and must involve greater interaction and collaboration among fishery scientists, archaeologists and anthropologists.

\section{INTRODUCTION}

The Pacific Islands were among the last areas of the Earth to be settled by humans. In most of these islands settlement occurred within the last two to three millennia. The major challenge facing new colonists arriving on uninhabited Pacific Islands was to maintain a sustainable source of food, from both land and sea. One of the most accessible sources of food is found in the coastal zone, along the tidal zone and rock pools where molluscs and small fish can be gathered or caught. Although contemporary Pacific Island human populations have a wider range of foods available than at any time in the past, fish and other seafoods form a major component of their diet. Further, in many locations Pacific Islanders continue to derive substantial nutrition from small fish and invertebrates obtained by gleaning on reef flats and in rock pools at low tides.

It is reasonable to suppose that where human populations flourished on the Pacific Islands following initial colonization, harvesting pressure markedly increased on the most accessible food resources, such as molluscs and other sessile invertebrates on shallow reefs and lagoons. Adaptation to declines in food supply from such sources would have been vital if postcolonization island populations were to survive, and would have required the development, or at least an improvement, of animal husbandry, horticulture, and hunting and fishing skills to ensure food security. Further, human activities, such as fishing and collecting from reefs and even agriculture, have the demonstrable capacity to markedly affect and change the environment. Such activities are also likely to have had an impact on coastal fisheries resources, and human populations would have had to adapt to these and other physical perturbations, such as prolonged drought, cyclones, tsunami, sea level changes, and tectonic uplift.

In this article I examine some of the archaeological and historical evidence for impacts on coastal fisheries resources by early human populations in the Pacific Islands. Pre-historic populations accumulated extensive middens over centuries and millennia. These contain 
mollusc, crustacean and echinoderm shell fragments, teleost and elasmobranch skeletal remains, and fishhooks manufactured from shell, bone, wood, and stone. The archaeological evidence assembled from midden sites in the Pacific Islands tends to support the sequence of events outlined in the previous paragraph, particularly with respect to molluscan resources. The cultural memory of how human populations responded to the changes in their food supply have ultimately evolved into the traditions of marine tenure and regulation observed in contemporary Pacific Island societies, and can be generally subsumed under the definitions of traditional fisheries management practices. Documentation of these various codes of ownership and regulation and the mechanisms by which they work are now widely available. ${ }^{1}$ In this article I attempt to provide a longer temporal context for these other contributions, by making a synthesis of historical and archaeological evidence from which the effects of longterm exploitation of subsistence coastal fisheries resources in the Pacific Islands may be inferred.

As is clear from other studies, these traditional regulatory systems are generally on the wane in many places in the Pacific as urbanized lifestyles and general modernization replace traditional village life. ${ }^{2}$ However, coastal fisheries resources continue to be a major staple in the diets of most of the Pacific Islands and a source of income for island people, to their continued productivity must be ensured. Further, there is a growing consensus that one of the major challenges for the Pacific Islands in the twenty-first century will be the demand placed on coastal fisheries resources from neighboring East and Southeast Asia. ${ }^{3}$ Indeed, almost all the commercial nearshore invertebrate fisheries production, such as molluscs for mother-ofpearl and sea-cucumbers for bLche-de-mer, currently supply East and Southeast Asian markets. And there is now growing interest in live coastal reef fish from the same markets.

Most Pacific islands, however, have small fisheries administrations, with little or no research capacity to gather the comprehensive information required for management. Consequently, coastal fisheries management in much of the South Pacific is largely based on intuition rather than on collected observations and experience. Johannes (1994) ${ }^{4}$ has argued that this very problem is an opportunity to seek a new paradigm for fisheries management in the South Pacific - one that is not based on the conventional approach of intensive data gathering and analysis, but based on self-reinforcing feedback systems at the local level. What I hope is demonstrated from this contribution is that much of the information relevant to understanding the long-term effects of exploitation of Pacific Islands coastal marine resources can be gathered from the historical and archaeological record, and can be combined in contemporary approaches to coastal fisheries management.

\section{HUMAN SETTLEMENT OF THE PACIFIC ISLANDS}

A short chronology of the settlement of the Pacific Islands is given here, with the sections concerned with pre-historic settlement based largely on Belwood (1980) ${ }^{5}$ and Irwin (1992) ${ }^{6}$, and the advent of European exploration and annexation summarized from Howe (1984) ${ }^{7}$ Humans first appeared in the Pacific from the west towards the end of the late-Pleistocene era, about 40,000 years BP (Before Present), as populations of hunter-gatherers, probably of Asian origin, moved from island-to-island through the Indonesian chain to the New Guinea mainland, the New Guinea Islands, and probably the Solomon Islands. During this period sea levels were lower than at present, and it is thought that crossing between islands was accomplished on simple rafts and canoes. Then, as today, it is possible to journey from the Asian mainland via Indonesia to the tip of the Solomon Islands without losing sight of land. Further intrusion into the Pacific required greater sailing and navigational skills, and thus the transit from the Solomon Islands to the Vanuatu archipelago and the islands beyond was not possible for these simple voyagers.

Current evidence for the earliest settlement in the New Guinea Islands is 32,000 BP, in New Ireland, and 28,000 years BP in Bougainville, at the northern end of the Solomon=s chain. The people of the New Guinea Highlands and Australian Aboriginals are remnant populations 
of these initial migrations, and are termed collectively Australoids. About 3,500 to 4,000 years BP, a second wave of migrants moved through Melanesia from Southeast Asia. These new migrants, were characterized by the manufacture of distinctively stamped and incised pottery, known as Lapita, named from an excavation site in New Caledonia. Unlike the initial Australoid populations, they had developed the outrigger canoe and sailing, which made journeys over broader expanses of water much safer; and they had developed the culture of root crops and pig farming. These agrarian advances encouraged settlement of other lands, some of which would have been unable to support a terrestrial hunter-gatherer existence. The new migrants demonstrated racial and linguistic affinities with contemporary East Asian mainland populations and spoke related languages in the large Austronesian family.

Over the next 500 years this Austronesian-speaking Lapita culture spread through the Melanesian islands, via Vanuatu, New Caledonia and Fiji, to Tonga and Samoa, some 5,000 $\mathrm{km}$ distant in the central Pacific. The settlers in Tonga and Samoa became the ancestors of the modern Polynesians. Later migrations northwards from Melanesia, between 2,000 and 2,500 years BP, colonized the islands of eastern nuclear Micronesia (Kiribati, the Marshall Islands, and the eastern Caroline Islands), with an earlier migration, probably from the Philippines, around 3,500 BP colonizing the islands of western Micronesia (the Marianas, Palau and Yap). Early in the first millennium AD the western Polynesians began a third phase of voyages to colonize the islands of central and eastern Polynesia, to the east of the Andesite Line. This marks the boundary between the islands of the continental regions of the Western Pacific and the volcanic mountains on the Pacific Plate, which push to the surface to form small high islands and atolls. The Marquesas, and possibly the Society Islands, were probably settled in $300 \mathrm{AD}$, during this third phase, and Easter Island perhaps a century later. Over the next 500 years, the fourth and final phase of migrations by the Polynesians resulted in the settlement of Hawaii and New Zealand, on the margins of Oceania. A summary of the various entries and dispersions of human populations in the Pacific is given in Figure 1.

The era of European exploration of the Pacific commenced in with Magellan who was followed by Dutch explorers, such as Tasman and Schouten, and British and French explorers, such as Dampier, Cook and Bougainville over the next three centuries. Howe (1984) ${ }^{7}$ suggests that it is easy to overestimate the European impact on the Pacific Island communities before 1800. Overall some 300 years of European exploration had either a minimal or no immediate effect on Pacific lifestyles. Indeed, the impact of the discovery of the Pacific Islands was probably far more noticeable in Europe, where as well as providing geographic enlightenment, the European discoveries made a major contribution to political, economic and intellectual developments in the Old World. ${ }^{7}$ The accounts of explorers, particularly after the mid-eighteenth century, generated European commercial and missionary interests from about 1800 onwards, and the steady annexation of the Pacific proceeded throughout the nineteenth century, until by 1900 Tonga was the only independent island nation left in the region. Apart from the Spanish possession of the Mariana Islands, annexed in 1565, all the remaining islands of the Pacific were colonized during the latter half of the nineteenth century.

Sometimes islands changed colonial administrations owing to conflict between the colonial powers. The Spanish-American war of 1898 saw Spain relinquish possession of the Mariana Islands to the USA. And following WW I, German possessions in Micronesia, Melanesia and Polynesia were re-distributed to Japan, Australia and New Zealand, respectively. During WW II, Japan controlled most of Micronesia and much of northern Melanesia (Papua New Guinea \& Solomon Islands). Following WW II, Japanese Pacific possessions in Micronesia were placed in the stewardship of the USA until, in the mid-1980s, these either chose to remain American territories or opted for independence or free-association. The latter quarter of the 20 century has seen the influence of the colonial administrations decline as 14 new independent countries emerge and greater autonomy given to the remaining territories. 


\section{THE ARCHAEOLOGICAL RECORD OF ANTHROPOGENIC EFFECTS ON PACIFIC COASTAL FISHERIES RESOURCES}

Dalzell and Adams (1996) ${ }^{8}$ have presented a brief review of archaeological information on coastal fisheries exploitation with respect to reef fisheries sustainability. In this contribution the results of archaeological investigations of natural resources at seven Pacific Island sites are discussed in greater detail. These sites are Matenkupum (New Ireland, Papua New Guinea), Tongatapu (Tonga), Mangaia (Cook Islands), Tikopia (Solomon Islands), Mussau (northern Papua New Guinea), Kapingamarangi and Nukuoro (Caroline Islands), and Aitutaki (Cook Islands).

\section{Matenkupum (New Ireland, Papua New Guinea)}

Archaeological excavations at Matenkupum on New Ireland, PNG) have uncovered fish bones and molluscs remains dating from the late-Pleistocene era, at 32,000 years BP. According to Allen et al (1989) ${ }^{9}$, these are the earliest evidence of the human capture of marine fish anywhere in the world, making this location also the world=s oldest continuously exploited reef and lagoon fishery.

The midden sites contain crab, lobster and sea urchin shells, teleost and elasmobranch skeletal material, and turtle and crocodile bones. The marine shellfish comprise a wide variety of species that derive predominantly from the intertidal reef zone or coastal fringing mangroves, with shell densities greatest at between 32,000 to 20,000 BP. Shells deposited in the Matenkupum midden in the earliest levels were mainly large individuals from large species, while the uppermost layers contained the fewest large species and the smallest mean sizes of species. These patterns reflect low levels of human predation on largely pristine mollusc populations, and indicate that some form of rotational cropping of the shellfish populations was probably practiced by these early colonists on New Ireland. ${ }^{9}$

Allen et al (1989) ${ }^{9}$ note that there was no evidence of consumption of fish inhabiting the outer reef slope or the open sea, with fish remains confined to species from the shallow reef zone. This is also the case in much of present day Melanesia. Further, neither evidence of fish hooks have been found from the late-Pleistocene strata in the middens nor evidence of their manufacture that have been found in other Pacific sites. Allen et al assumed therefore that fish were taken either by netting, spearing, poisoning, and stone weir traps on the reef flat.

\section{Tongatapu (Tonga)}

Elsewhere in the Pacific most archaeological studies concern the Lapita civilizations, the ancestors of the modern Polynesians, Micronesians and coastal Melanesian populations. This gives a time frame for most archaeological evidence of between 3,500 years BP to 300-400 years BP, or to the period shortly before European contact. As was evident from the data from the late- Pleistocene example from Papua New Guinea, pre-historic island populations may have heavily exploit sedentary invertebrates, particularly molluscs, as evident from shell middens.

Spennenman (1987) ${ }^{10}$ showed that the initial human population on Tongatapu (Tonga) were heavily reliant on the molluscs from the adjacent lagoon and reefs, especially Anadara antiquata, Gafrarium tumidum and G. gibbosium. At the time of initial settlement of Tonga, between 3,000 to 3,500 years BP, Fanga=Uta Lagoon on Tongatapu was much larger than at present. The reduction in the size of the lagoon is though to have resulted from a combination of tectonic uplift and falling sea levels. The reduction in the lagoon area was accompanied by dilution of the lagoon water, which lowered salinities and favored the Gafrarium spp., while putting A. antiquata at a distinct disadvantage. During the period between 3,500-2,000 years BP, Anadara spp. gradually declined in importance, due partially to exploitation but also to increasing dilution of the seawater in Tongatapu Lagoon. In contrast, Gafrarium spp. became more common in the shell middens. 
Spennenman $(1987)^{10}$ obtained an age-at-size relationship for G. tumidum from spawning checks on the shell, by assuming that each mark was deposited annually. The size frequency distributions of G. tumidum in the various midden levels were then converted into age frequencies from which survivorship curves could be calculated. The survivorship curves for the G. tumidum showed that the population age composition shifted with time toward younger smaller molluscs during the late-Lapita Period on Tonga. This has continued to the present. Spennenman (1987) ${ }^{10}$ concluded that diminishing shellfish returns both in quality and quantity marked the subsistence economy of the late-Lapita Period. As a response to the declining shellfish resource, the human population of Tongatapu was forced to expand horticulture in inland areas, increase pit construction for food storage, and increase the proportion of pig in the diet, as evidenced by the greater amount of pig bones in the lateLapita Period. The declining shellfish resource may also have been marked by an intensification of the exploitation of reef and lagoon fish, although the evidence for this is mostly circumstantial. Spennenman notes, however, that osteoarthritic changes in human spines from skeletons dating from 800 to 600 years BP indicate that canoeing and presumably fishing was a daily occurrence, although no fish bones have been recovered from archaeological strata of that date.

\section{Tikopia (Solomon Islands)}

Excavations on Tikopia, a Polynesian outlier in the Solomon Islands, suggest a similar pattern of pre-historic exploitation to that observed in Tongatapu. Tikopia was colonized about 3,000 $\mathrm{BP}$, and mollusc resources appear to have been a major source of animal protein for the initial colonizers, especially ark shells and other clams such as Periglypta spp., Atactodea spp., and the gastropod Strombus strombus (Kirch \& Yen 1982). ${ }^{11}$ In common with Tongatapu, environmental changes also had an influence on mollusc exploitation. Present day Tikopia has a shallow coastal brackish lake or Abongo@ that previously was a circular bay with a narrow entrance. Kirch \& Yen (1982) ${ }^{11}$ suggest that the lake entrance silted up, possibly as a result of agricultural activities on slopes around the bay contributing to sediments in the runoff and tectonic uplift of the coastal margin. After the bay was sealed and became a brackish lake, the mollusc resource declined in importance in the diet. Pig became increasingly more important as a source of animal protein, and there was a greater reliance on agriculture in general.

A variety of shore fishes comprise the ichthyofaunal remains found by Kirch \& Yen (1982). ${ }^{11}$ They found that porcupinefish (Diodontidae) and moray eels (Muraenidae) were particularly evident in the lower levels of the archaeological strata, but disappeared from the record in the post-Lapita Period. Indeed, there is now a customary taboo on the consumption of these fishes on Tikopia. Kirch \& Yen suggest that repeated incidences of ciguatera poisoning may have led the pre-historic Tikopians to avoid and ultimately proscribe porcupinefish and moray eels from the diet. Ciguatera is certainly common in moray eels where this form of ichthyosarcotoxism is probably more prevalent than in most other reef species (porcupine fish are not associated with ciguatera and toxicity is more likely to be related to very potent tetrodotoxins concentrated in the gonads, liver and intestines of porcupinefish and other related pufferfishes). Kirch (1988) $)^{12}$ noted that a similar situation occurred at Niutoputapu, where diodontids were also common in excavations but never eaten by the contemporary population. Similarly, Leach \& Davidson $(1988)^{13}$ found that moray eels and pufferfish (although not porcuinefish) had been actively avoided for about a millennia by fishers on the Micronesian atoll of Nukuoro (see below), although they are common on the reefs and were actively targeted over the same period by fishers on the neighboring Kapingamarangi atoll. Porcupinefish remains are a common feature of such Polynesian archaeological sites as Aitutaki, in the Cook Islands (Allen 1992) ${ }^{14}$, and Rurutu, in French Polynesia,and are still consumed in some parts of Polynesia and Fiji, despite the associated health risk ${ }^{15}$ 
Changes in the abundance of mollusc populations may also have had a profound influence on fishing technology and the resources exploited by pre-historic populations of Pacific Islands. Allen (1992) ${ }^{14}$ notes that earlier sequences (1000 BP) in archaeological excavations at Aitutaki, in the southern Cook Islands, contain hooks made from the shell of the pearl oyster (Pinctada margaritifera), but these are replaced in later sequences (550-450 BP) by hooks made predominantly from the turban shell (Turbo setosus). The decline in pearl shell hooks at Aitutaki (and at other islands in the southern Cook Islands) may have resulted from a general breakdown in communication between the islands, which involved the loss of exchange materials such as pearl shell (Walter 1990). ${ }^{16}$ Allen $(1992)^{14}$, on the other hand, argues that as pearl oysters are locally available at Aitutaki, declines in pearl shell hook manufacturing may have been due to cumulative changes in the local marine environment, and, in particular, gardening on the eastern side of the island that accelerated terrigenous sedimentation of the lagoon and caused a decline in the pearl oyster population. However, contemporary pearl oyster populations are extremely low at Aitutaki, as observed during fisheries resource assessment surveys in 1992 and 1995 (Adams et al 1995 ${ }^{17}$, I. Betram pers. comm.), and the shallow enclosed lagoon is not particularly suitable for maintaining high densities of this species. It is possible that $P$. margaritifera was never locally common.

Whatever the reason, the loss of availability of pearl oyster forced a shift to the use of turban shell hooks by fishers at Aitutaki. However, turban shell and pearl oysters represent two different basic shell structural types. As summarized by Allen $(1992)^{14}$, turban shell has a composite structure that includes both an outer prismatic layer and aragonite and a pearly inner laminar layer. A thin inclined prismatic layer also overlies this inner layer. This makes the turban shell very hard but not very elastic. Pearl oyster shell, in contrast, is a nacreous structure in which tabular aragonite crystals are arranged in layers with an organic matrix. These nacreous structures are most resistant to breakage in tension, compaction, impact, and bending. Based on the composition changes in fish bone assemblages at Aitutaki, Allen $(1992)^{14}$ suggests that the reliance on weaker hooks forced fishers to fish predominantly in the Aituaki lagoon for smaller fish which would not break the turban shell hooks, as opposed to fishing for large carnivorous species, such as snappers (Lutjanidae) and groupers (Serranidae), on the outer reef slope, and to increase the frequency fishing methods other than angling. Allen cites as evidence for this the decline in the relative abundance of snappers (Lutjanidae), which are caught mainly on the outer reef slope, and the increase in the importance of triggerfish and porcupinefish, which were thought to be caught mainly by net fishing. Allen also predicts that further study may reveal that Aitutaki serranid remains change through time to species from predominantly outer reef slope taxa to species more commonly caught in shallow inshore waters

\section{Mangaia (Cook Islands)}

Excavations in a rock shelter at Mangaia, in the Cook Islands, by Kirch et al (1995) ${ }^{18}$ showed sustained exploitation between 980 to 330 years BP of the gastropod Turbo setosus, an important species used throughout Polynesia both for food and making shell fishhooks. Kirch et al (1995) $)^{18}$ found that the average size of the operculae of $T$. setosus in the middens decreased by $50 \%$ between the earliest layers in the sequence and those in later years, a period of about 500 years. There is a significant increase in the frequency of molluscan remains at about the middle of the sequence (500 years BP) and which continues thereafter. Similar increases were noted with sea urchin tests and spines. But crustacean remains, which were initially abundant, declined markedly to only small quantities in later layers. Kirch et al $(1995)^{18}$ note that at the time of European contact, the population of Mangaia was at least 2,000-3,000 people, and may have been higher (the present day population is about 1,300 people). This was one of the most densely populated islands in central Polynesia, in which both terrestrial and nearshore marine faunas were limited. Not surprisingly, there was intense competition for these resources, particularly the arable land for growing taro, the chief root crop staple. 
Kirch et al (1995) ${ }^{18}$ found that reef and freshwater-brackish fishes formed most of the bones deposited between 980 to 330 years BP. Of the marine fishes, acanthurids, labrids, serranids, and cirrihitids (hawkfish) were the most common in the excavation site. The abundance of hawkfish (15\%) in the fish bone composition has not been noted elsewhere in Oceania, and it is not known if this reflects local abundance on Mangaia=s reef or the development of a specialized fishing strategy to catch these species. The other unusual feature of the Mangaia excavationsCamong Pacific Island sitesCwas the prominence of fresh and brackish water fishes, particularly the freshwater eels (Aguillidae) and gudgeons (Eleotridae), comprising respectively 6 and $22 \%$ of the fish bone assemblage. Eleotrids are a common feature of the streams and lakes on Mangaia, and were caught in the past by netting, handlines and with gorges (Buck 1944). ${ }^{19}$ An analysis of the fish bone assemblages from Mangaia by Butler $(1993)^{20}$ suggests that there was no significant reduction in the body size of the coral reef fishes and eleotrids. However, the data did suggest that intensive fishing for anguilids led to a reduction in size in the population with time and decline in the relative abundance in the bone assemblages.

\section{Kapingamarangi and Nukuoro (Federated States of Micronesia)}

External analyses of fishing folklore and traditions may suggest that certain fish species are of particular nutritional importance for island communities. However, this totemic assumption may be given undue importance, and evidence from other sources sometimes suggests the contrary. Leach \& Davidson (1988) ${ }^{13}$ report on the cultural importance of the rainbow runner on Nukuoro and Kapingamarangi, two Polynesian outlier atolls in Micronesia. The rainbow runner (Elegatis bipinnulatis) is held in great esteem in both islands, is a subject of folklore and song, and would appear to be both the most sought after species and the most frequently caught on both atolls. However, Leach \& Davidson ${ }^{13}$ found from the historical record from excavations (to between 500-700 years BP on Nukuoro and 750 and 1,050 years BP on Kapingamarangi) that the importance attached to rainbow runners is symbolic rather than being truly important as a food fish.

Historically, the bulk of landings (85\%) from both atolls were groupers, parrotfish, eels, triggerfish, and jacks, all fishes that are taken on the reef or in the lagoon. Leach \& Davidson $(1988)^{13}$ suggest that the difficulty attached to catching large pelagics, such as rainbow runners, from non-motorized canoes makes them attractive and worthy of admiration and mystique, rather than the lagoon species, such as parrot fish, which are easily caught by netting or spearing. However, it is these proximate reef and lagoon species which have formed the basis of food security in many Pacific Islands, both in the past and at present. Nukuoro is renowned for the manufacture of fishhooks from pearl oyster shell, whereas on Kapingamarangi hooks are made mainly from such less durable materials as turtle shell and coconut shell. Leach \& Davidson ${ }^{11}$ note, however, that angling with baited hooks appears to be more productive on Kapingamarangi as opposed to Nukuoro, where netting appears to be main the method of fisheries production. The authors concluded that while medium sized and large pelagic fishes such as rainbow runners and tunas may have great socio-cultural importance to fishers on the two atolls, their economic role has been relatively insignificant over the last 1,000 years. The fishes most actively sought by fishers, even at the subsistence level, are not necessarily those most frequently caught.

\section{Mussau (Papua New Guinea)}

Excavations at Mussau, about $110 \mathrm{~km}$ north of New Ireland, have uncovered fish bone middens and trochus shell hooks extending between 3400 and 350 years BP (Kirch et al 1991). ${ }^{21}$ Many of the fish bones can be identified to the level of the family taxon, and the same eight families (Serranidae, Lutjanidae, Lethrinidae, Labridae, Scaridae, Acanthuridae, Balistidae, and Diodontidae) were prominent at all sites, comprising between 71-90 \% of the assemblages. Kirch et al (1991) $)^{21}$ note that there is very little change in the relative 
frequencies of the different families over a period of nearly four millennia. The results suggest a relatively stable reef fish fauna at Mussau, with subsistence fishing pressure by prehistoric human populations having little influence on the various reef fish populations.

Butler (1988) $)^{22}$ showed that the fish bone assemblages from Mussau are similar to other Lapita sites in the western and central Pacific, and that the eight families listed above account for more than 85 \% of fish remains at sites in the Solomon Islands, Fiji, Tonga, and Samoa. The same families (minus the Diodontidae) still form between 22 and $70 \%$ of landings in contemporary reef fisheries landings in the South Pacific, with an overall mean among countries of $50 \%$ (Dalzell et al 1996). ${ }^{23}$ The major difference between Mussau and the other Lapita sites is the relative unimportance of Diodontidae, which form just over $5 \%$ of the Mussau fish bone assemblages, but between 6.5 and $41.5 \%$ (mean $=21 \%$ ) of fish bone assemblages elsewhere.

Later analyses by Butler (1994) ${ }^{24}$ compared the family composition from fish bones in Lapita sites in Melanesia, including Mussau, and Polynesia. Most western Melanesian assemblages, such as at Mussau, are comprised of similar frequencies of carnivores and herbivores/omnivores, but eastern Lapita site assemblages are dominated by herbivores/omnivores. Butler suggests that the faunal assemblages are possibly explained by differences in fishing strategies. Hook-and-line, fishing, spearing and net fishing appear to have been widely practiced in the western Lapita sites, whereas in the east hook-and-line fishing, which catches predominantly carnivores, was less common. Another possible interpretation, however, might be that the reduction in reef carnivores in the eastern Lapita sites resulted from a higher fishing pressure, which reduced the populations of these species, since that would be in accord with contemporary differences in the trophic composition of fish catches between Polynesia and Melanesia (Adams \& Dalzell n.d.). ${ }^{25}$

\section{DISCUSSION}

I have attempted to show that a rich vein of information about long-term subsistence fisheries exploitation of reef and lagoon fisheries resources in the Pacific Islands can extracted from archaeological records. The examples given here demonstrate some of the various aspects that can be gleaned from an admittedly cursory reading of the archaeological record. They can be broadly summarized as follows:

Reef and lagoon fisheries resources in the Pacific have been subjected to continuous exploitation for many centuries, and in Western Melanesia for periods of between 20 to 30 millennia, making them some of the oldest known continuously exploited reef fisheries in the world;

Mollusc resources appear to have been extremely important as a food source for early Pacific Island human populations. In some instances declines in mollusc resources forced early human populations to expand exploitation of other marine resources, and to develop a greater reliance on agriculture;

The paleo-ichthyological record suggests that the sustained effects of exploitation of sessile invertebrates, such as molluscs, can be quantitatively determined from shell assemblages, and that long-term subsistence exploitation can in some cases markedly reduce the average size composition of mollusc populations and species structure of communities;

Decline in populations or loss of supply of some molluscs, such as the pearl oyster, can also have a marked effect on fishing technology and target species, as was the case on Aitutaki;

The pre-historic record with respect to fish exploitation is less conclusive. There does not appear to be much strong evidence that long-term subsistence exploitation of reef fish has had much impact on reef fish populations. Smaller more accessible fish populations, such as freshwater eels, may be more vulnerable to sustained exploitation; 
The archaeological record for subsistence reef fin-fisheries suggests long-term stability, with changes in relative composition of different fish taxa in the temporal sequence perhaps resulting more from other factors, such as changes in fishing technology, or repeated cases of ichthyosarcotoxism affecting human behavior; and

Some differences in catch composition of fin-fish between western and eastern Lapita sites reflect differences in absolute levels of fishing activity observed in contemporary Melanesian and Polynesian populations, and their effects on the abundance of larger carnivorous species may not simply reflect differences in the fishing methods employed.

Apart from a record of the impacts of exploitation, another important aspect of the archaeological and historical record is its potential reinforce the social and cultural importance of fisheries, and traditional property rights, even though these may have declined through progressive urbanization and European colonization in the Pacific Islands. This latter point has been amply demonstrated in New Zealand (Aotearoa), where the original Polynesian Maori population was economically and socially marginalized following European settlement in the nineteenth century. As a consequence of European settlement, indigenous Maori property concepts and rights with respect to fisheries resources were not recognized and the rights of indigenous fisheries were generally usurped. As the Maori population declined and laws effectively dispossessed them of their fishing rights, the European settlers, who were initially minor users of marine resources, gradually came to dominate fishing. By the late-nineteenth century Maori fishing had declined to subsistence activities, leading, until recently, to the perception by modern New Zealanders that Maori fishing practices in the past were limited to little more than near-shore gleaning of shellfish (Waitangi Tribunal $1988^{26}$; Ruddle $1995^{27}$ ).

However, many early European explorers recorded a range of diverse fishing activities as well as expertise in seamanship and navigation among the Maori. Some traditional fishing grounds were up to $40 \mathrm{~km}$ from shore, and the Maori regularly made catches numbering many thousands of fish with large seine nets (Ruddle 1995) ${ }^{27}$. Further, fishing played a central role in the traditional economy of the Maori, in trade and barter between coastal and inland tribes, and latterly between Maori and initial European settlers and whaling vessels (Waitangi Tribunal 1988) ${ }^{26}$. Archaeological studies have also produced evidence of a diverse range of Maori fishing activities exploiting a wide range of fishes and marine mammals, such as seals, including the preservation of large amounts of fish (see sources listed in Waitangi Tribunal $1988^{26}$ and $1992^{27}$ ). Indeed in some areas, such as the Muriwhenua region of New Zealand=s North Island, fishing became a principal source of nutrition as human populations increased and food from hunting and agriculture became increasingly limited. Such evidence has been successfully used by the Maori people in New Zealand in seeking restoration of the recognition of traditional fisheries property rights, as were guaranteed under the 1840 Treaty of Waitangi.

As this example also demonstrates, the patterns of fisheries exploitation in the South Pacific were irrevocably changed from the period of European expansion in the region, at the beginning of the nineteenth century. Apart from colonial settlement on the Pacific Islands, European, American and Asian traders also entered the region, and the era of commercial fishing commenced.

The pre-historic record has shown that subsistence exploitation can have a noticeable influence on sessile invertebrates but that these can continue to be productive over many centuries. The scale of commercial exploitation during the nineteenth century demonstrated how susceptible sessile invertebrates over a wide area could be to very heavy levels of exploitation. An excellent example is the history of the Fiji bLche-de-mer trade between 1828 and 1842. The harvesting or fishing for sea cucumbers (Holothuroidea) for processing in to the dried product, bLche-de-mer, is one of the oldest commercial fisheries in the South Pacific, together with pearl oysters. Sea cucumbers are not a staple of the subsistence diet of 
Pacific Islanders but are consumed in a few locations only as a condiment. Prior to European contact, therefore, sea cucumber populations were subject to minimal fishing pressure. The growth of the bLche-de-mer trade in the Pacific during the nineteenth century has been documented by Ward (1972) ${ }^{28}$ and Conand (1990) $)^{29}$. Spanish, Australian and American vessels operated throughout the Pacific during the first half of the nineteenth century trading for both bLche-de-mer and sandalwood. The main target species for the bLche-de-mer trade, then as now are sandfish (Holothuria scabra), white teatfish (Holothuria fuscogilva) and black teatfish (Holothuria nobilis), with less valuable species, such as blackfish (Actinopyga miliaris) and prickly redfish (Thelanota ananas), also contributing to harvests. Then, as now, the main market for bLche-de-mer was China.

The center of the bLche-de-mer trade by the mid-nineteenth century was Fiji, where there was a massive increase in exploitation between 1828 to 1848 (Ward $1972^{28}$; Adams $1988^{30}$ ). During this 20-year period, an estimated 1000-1500 tonnes of dried bLche-de-mer were exported. Adams (1988) states that very little fishing for bLche-de-mer occurred between 1835 and 1842, giving an average annual export of around $100 \mathrm{t}$ /yr. By 1852 the stocks of bLche-de-mer in Fiji from the most productive waters in Bua, Macuata and Ra were near exhaustion. At this time the high chief of Fiji, Ratu Seru Cakobau, ordered two sloops from the USA and Australia, and tried raising the revenues for these by bLche-de-mer harvesting. The chiefs= entire army of several hundred men was deployed in over 100 canoes, but failed to collect more than $32 \mathrm{t}$ of bLche-de-mer, far less than the price of the vessels. A party of Fijians was then dispatched to New Caledonia to collect enough bLche-de-mer to pay for only one vessel. Anecdotal accounts from the period suggest that some reefs recovered quickly from this over-exploitation, whereas others showed no signs of recovery, even after 20 years (Adams 1988).

Bayliss-Smith $\left(1974,1980^{31}\right.$ ) has suggested that in the tropical Pacific an island=s carrying capacity for human populations was primarily a function of the land area available and the volume of taro (Colocasia spp. and Cyrtosperma spp.) that could be cultivated. Competition for coastal fisheries resources may also have been a limiting factor, especially on small islands where human population densities were high. The impact of western civilization on Pacific populations was initially disastrous in many locations, leading to wholesale human population decline through disease, slavery and migration (McArthur 1967). ${ }^{32}$ Indeed it is likely that fish catches from reefs and lagoons declined in many locations in the Pacific during the nineteenth century as human populations were reduced. In contemporary Pacific populations imported foodstuffs have partially replaced fish in the diet in many locations, but demand is still high and will continue to grow as human populations increase. Subsistence and commercial reef and lagoon fisheries must therefore continue to play an important role in the food security of the South Pacific, but it is generally believed that comparatively little is know about them, particularly their sustainability. As this paper has attempted to demonstrate, much information is available from a variety of sources other than contemporary fisheries literature.

Finally, it is important to note too how new Atraditions@ have arisen in the Pacific during the past two centuries since European expansion. One of the most striking is the advent of Christianity, and in particular the Seventh Day Adventist Church. Adherents of this creed follow a broadly dietary code (based on verses from the books of Deuteronomy and Leviticus in the Old Testament) that proscribes, among other things, fish without scales (sharks) and shellfish. Islands such as Mussau, discussed earlier, where the population is now predominantly Adventist, are havens for marine molluscs, crabs, lobsters, prawns, and even higher vertebrates such as turtles and dugongs, which are also not eaten. Clearly, such islands may be important from a conservation and management viewpoint as refuges and reservoirs for breeding populations. The concept of closed areas or marine reserves as a management tool for reef fisheries is gaining increasing interest globally (Roberts \& Polunin 1991, 1993) ${ }^{33}$. Islands in the Pacific with large Seventh Day Adventist populations could be factored into 
marine reserve studies and management strategies. This final point is included to encourage fisheries managers in the Pacific to develop and adopt novel multi-disciplinary approaches to coastal fisheries management, by making use of a broader range of information sources as inputs into the management process, particularly where conventional fisheries data is either poor in quality or completely lacking.

\section{ACKNOWLEDGEMENTS}

I thank Tim Adams and Reg Sanday, of the South Pacific Commission, for their comments on this paper, and Dr Virginia Butler of Portland State University, Oregon, for help with understanding the archaeological literature. The Overseas Development Administration of the Government of the United Kingdom financially supported most of the preparation of this work through their assistance to the South Pacific Commission's Integrated Coastal Fisheries Management Project.

\section{REFERENCES}

1. Ruddle, K., A Guide to the Literature on Traditional Community Based Fishery Management in the Asia-Pacific Tropics (FAO Circular No. 869). Food and Agriculture Organization of the United Nations, Rome, 1994.

1. Ruddle, K., External forces and change in traditional community based fishery management systems in the Asia-Pacific region. Maritime Anthropological Studies, 6, 1994, 1-37.

1. Crocombe, R. Workshop overview. In Traditional Marine Tenure and Sustainable Management of Marine Resources in Asia and the Pacific, G.R. South, D. Goulet, S. Tuqiri \& M. Church (eds.) Suva: International Ocean Institute-South Pacific, 291300.

1. Johannes, R.E. Design of tropical nearshore fisheries extension work beyond the 1990s. In Traditional Marine Tenure and Sustainable Management of Marine Resources in Asia and the Pacific, eds. G.R. South, D. Goulet, S. Tuqiri \& M. Church, International Ocean Institute-University of the South Pacific, 1994 pp. 162174.

2. Bellwood, P.S. The peopling of the Pacific. Scientific American, 243(5) (1980) 138147.

3. Irwin, G. The prehistoric exploration and colonisation of the Pacific. Cambridge University Press, 1992.

4. Howe, K. R. Where the waves fall (Pacific Islands Monograph Series No 2). University of Hawaii Press 1984.

5. Dalzell, P. \& Adams, T. Sustainability and management of reef fisheries in the Pacific Islands. Paper presented at 8th International Coral Reef Symposium, Panama, 1996.

6. Allen, J. C. Gosden \& White, J.P. Human Pleistocene adaptations in the tropical island Pacific: recent evidence from New Ireland, a Greater Australian outlier. Antiquity, 63 (1989) 548-561.

7. Spennenman, D.H.R. Availability of shellfish resources on prehistoric Tongatapu, Tonga: effects of human predation and changing environment. Archaeology in Oceania, 22 (1987) 81-96. 
8. Kirch, P.V. \& Yen, D.E. Tikopia: the prehistory of a Polynesian outlier (B.P. Bishop Museum, Bulletin No. 238). Hawaii, 1982.

9. Kirch, P.V. Niuatoputapu: the prehistory of a Polynesian chiefdom (Thomas Burke Memorial Washington State Museum Monograph No. 5), Seattle 1988.

10. Leach, B.F. \& Davidson, J.M. The quest for the Rainbow Runner: prehistoric fishing on Kapingamarangi and Nukuoro Atolls, Micronesia. Micronesica, 21 (1988) 1-22.

11. Allen, M.S. Temporal variation in Polynesian fishing strategies: the Southern Cook Islands in regional perspective. Asian Perspectives, 31(2) (1992) 183-204.

12. Pers. comm. J. Dashwood and T. Adams, both of SPC.

13. Walter, R. The Southern Cook Islands in Eastern Polynesian prehistory. Ph.D. thesis, Auckland University (1990).

14. Adams, T., Nash, W., Tuara, P., Munro, D., Amos, M., Leqata, J., Terekia, O., Mataiti, N., Teopa, M. \& Whitford, J.The Aitutaki trochus fishery: a case study (Inshore Fisheries Research Project Technical Document No. 9). South Pacific Commission, New Caledonia, 1995; and Betram, pers. comm.

15. Kirch, P.V., Steadman, D.W., Butler, V.L., Hather J. \& Weisler, M.I.. Prehistory and human ecology in Eastern Polynesia: excavations at Tangatatu rockshelter, Mangaia, Cook Islands. Archaeology in Oceania, 30 (1995) 47-65.

16. Buck, P.H. Arts and crafts of the Cook Islands (B.P. Bishop Museum Bulletin No. 157), Honolulu, 1944.

17. Butler, V.L. Measuring effects of prehistoric predation and habitat alteration on fishes, Mangaia, Cook Islands. Paper presented at the Society for American Archaeology Meeting, St Louis, Missouri, 1993.

18. Kirch, P.V., Hunt, T.L., Weisler, M., Butler V. \& Allen M.S.. Mussau Islands prehistory, results of the 1985-86 excavations (Occasional Papers in Prehistory No. 20). Department of Prehistory, Australian National University, Canberra, Australia, 1991 144-163.

19. Butler, V.L. Lapita fishing strategies: the faunal evidence. In Archaeology of the Lapita Cultural Complex: a critical review, ed. P.V. Kirch and T.L. Hunt, Thomas Burke Memorial Washington State Museum Research Report 5, Seattle, 1988 pp. 99115.

20. Dalzell, P., Adams, T. \& Polunin, N. Coastal fisheries in the Pacific Islands. Oceanography and Marine Biology: an Annual Review, 34 (1996) 395-531.

21. Butler, V.L. Fish feeding behaviour and fish capture: the case for variation in Lapita fishing strategies. Archaeology in Oceania, 29 (1994) 81-90.

22. Adams, T. \& Dalzell, P. Artisanal Fishing. Paper presented at the Workshop on Marine/Coastal Biodiversity in the Tropical Island Pacific Region, 2-9 November 1994, East West Center, Honolulu, Hawaii, in press.

23. Waitangi Tribunal. Muriwhenua Fishing Report (WAI 27). Department of Justice, Wellington 1988

24. Ruddle, K. 1995. The role of validated knowledge in the restoration of fisheries property rights: the example of the New Zealand Maori. In Property Rights in a 
Social and Ecological Context: part 2, Case Studies and Design Applications, eds. S. Hanna \& M. Munasinghe. The Beijer International Institute of Ecological Economics \& the World Bank, Stockholm and Washington D.C.

25. Waitangi Tribunal. 1992. Ngai Tahu Sea Fisheries Report (WAI 27). Brooker and Friend, Wellington.

26. Ward R. G. The Pacific bLche-de-mer trade with special reference to Fiji. In Man in the Pacific Islands, ed. R.G. Ward, Oxford University Press, 1972, pp. 91-123.

27. Conand, C. The fishery resources of Pacific island countries. Part 2 Holothurians (Fisheries Technical Paper No. 272.2). Food and Agriculture Organisation, Rome, 1990.

28. Adams, T. The disappearing dri. Fiji Times, 28 July, 1988.

29. Bayliss-Smith, T. Constraints on population growth: the case of the Polynesian outlier atolls in the pre-contract period. Human Ecology, 2(4) (1974) 259-293; BaylissSmith, T. Population pressure, resources and welfare: towards a more realistic measure of carrying capacity. In Population environment and resources in tropical islands: the case of eastern Fiji. ed. H.C. Brookfield. MAB Technical Notes, No. 13, UNESCO, Paris, 1980, pp. 61-93

30. McArthur, N. Island populations of the Pacific. Australian National University Press, Canberra, 1967.

31. Roberts, C.M. \& Polunin, N.V.C. Are marine reserves effective in the management of reef fisheries. Reviews in Fish Biology and Fisheries 1, (1991) 65-91; Roberts, C.M. \& Polunin, N.V.C. How marine reserves can benefit reef and fishers. Sea Wind 1 (1993) 2-7. 